\author{
Robert OLENIACZ ${ }^{1}$ \\ Marek BOGACKI ${ }^{2}$ \\ Adriana SZULECKA ${ }^{3}$ \\ Mateusz RZESZUTEK ${ }^{4}$ \\ Marian MAZUR ${ }^{5}$
}

\title{
ASSESSING THE IMPACT OF WIND SPEED AND MIXING-LAYER HEIGHT ON AIR QUALITY IN KRAKOW (POLAND) IN THE YEARS 2014-2015
}

\begin{abstract}
The paper discusses the role of wind speed and mixing-layer height in shaping the levels of pollutant concentrations in the air of Krakow (Southern Poland). The hourly averaged measurements of concentrations of selected air pollutants and wind speed values from the period of 2014-2015, recorded at two of the air quality monitoring stations within Krakow (both industrial and urban background) were used for this purpose. Temporal variability of mixing-layer height in the area of the monitoring stations was determined using numerical modelling with the CALMET model and the measurements derived from, i.a., two upper air stations. It was found that wind speed and mixing-layer height are in at least moderate agreement with the concentration values for some pollutants. For $\mathrm{PM}_{10}, \mathrm{PM}_{2.5}, \mathrm{NO}_{2}, \mathrm{NO}_{\mathrm{x}}, \mathrm{CO}$ and $\mathrm{C}_{6} \mathrm{H}_{6}$ correlation coefficient is of negative value, which indicates that the low wind speed and low mixing-layer height may be the dominant reason for elevated concentrations of these substances in the air, especially in the winter months. Moderate but positive correlation was found between $\mathrm{O}_{3}$ concentrations and analysed meteorological parameters, proving that the availability of appropriate precursors and their inflow from the neighbouring areas have an important role in the formation of tropospheric ozone. On the other hand, in case of $\mathrm{SO}_{2}$, a weak both positive and negative correlation coefficient was obtained, depending on the period and location of the station concerned.
\end{abstract}

${ }^{1}$ Corresponding author: Robert Oleniacz, AGH University of Science and Technology, Department of Environmental Management and Protection, Al. Mickiewicza 30, 30-059 Krakow, Poland, phone: +48 12 6174503, oleniacz@agh.edu.pl

2 Marek Bogacki, AGH University of Science and Technology, Department of Environmental Management and Protection, Al. Mickiewicza 30, 30-059 Krakow, Poland, bogacki@agh.edu.pl

3 Adriana Szulecka, AGH University of Science and Technology, Department of Environmental Management and Protection, Al. Mickiewicza 30, 30-059 Krakow, Poland, szulecka@agh.edu.pl

${ }^{4}$ Mateusz Rzeszutek, AGH University of Science and Technology, Department of Environmental Management and Protection, Al. Mickiewicza 30, 30-059 Krakow, Poland, rzeszut@ agh.edu.pl

5 Marian Mazur, AGH University of Science and Technology, Department of Environmental Management and Protection, Al. Mickiewicza 30,30-059 Krakow, Poland, mmazur@agh.edu.pl 
Keywords: air pollution, pollutant concentrations, meteorological parameters, correlation analysis, city ventilation, CALMET

\section{Introduction}

Air quality conditions within the given area are affected by numerous meteorological parameters, among which wind speed and the height (depth) of mixing layer are of great importance. These factors determine the pace of air masses movements and the potential processes of concentration and dilution of air pollutants comprised within, as a result of an air inflow from neighbouring areas, more or less polluted $[1,13,15,44]$. Wind is also a fundamental dispersing factor defining the spread direction of air pollutant plumes emitted from various emission sources, which leads to considerable diversity of pollution levels in the air caused by their influence.

For most substances, at higher wind speeds observed concentrations in the air decrease $[22,25,32,45]$, due to the intensified dilution of pollutants. The ventilation effect is of particular importance in the heating season, during which an increased emission from household fuel combustion and petrol vehicles cause the accumulation of pollutants in the city centre. Higher wind speed may also lead to the inflow of pollutants from further distances $[13,17]$ and can contribute to a possible increase in their concentrations in the air within the area where they were initially lower. On the other hand, in case of such secondary pollution as ozone, an increased wind speed may involve higher concentrations as a result of the inflow of precursors (mainly hydrocarbons) participating in the formation of this compound in tropospheric air together with the presence of nitrogen oxides $[2,10,24,37]$.

In the urban areas building configuration plays a significant role, as its unfavourable setup may considerably restrict the site ventilation [12]. Disturbance of ventilation conditions specific for high-density cities, where buildings block natural wind corridors, leads to accumulation of pollutants in the city centres $[6,25]$. Significant variation in terms of the wind speed influence on the pollutant concentrations is observed depending on the location of the measurement point [15]. For example, within urban street canyons, where road transport is primary emission source, air pollutants propagate differently compared to the open area $[14,16,21,30,39,41]$.

Mixing-layer height and the atmospheric stability occurring within the planetary boundary layer are relevant as well in terms of shaping processes of the air quality conditions in the areas subjected to strong anthropogenic pressure. Low height of mixing and stable atmosphere, which limit the vertical movements of air masses are, next to low wind speeds, primary factors responsible for episodes of elevated pollutant concentrations in the air (including $\mathrm{PM}_{10}$ and $\mathrm{PM}_{2.5}$ ) in many cities around the world, observed particularly in the winter $[4,11,17,18,28,29,35,38]$. 
Krakow city (Southern Poland) is characterized by notably adverse local meteorological conditions due to its location in the Vistula valley and specific landform associated with numerous hills and mountain slopes around the city. This positioning, combined with excessive condensation of multi-storey building clusters in Krakow are not conducive to the natural ventilation of the city, which is one of the main reason for frequent calm winds episodes and elevated pollutant concentrations in the air, especially in the winter period [25].

The aim of this study was to determine the effect of momentary wind speed and mixing-layer height on the observed concentrations of pollutants recorded at the two of air quality monitoring sites located in Krakow (Southern Poland): urban background station and industrial station (measuring the impact of industrial facilities). In the paper the results of continuous measurements from 2014 and 2015 of hourly averaged pollutant concentrations $\left(\mathrm{PM}_{10}, \mathrm{PM}_{2,5}, \mathrm{SO}_{2}, \mathrm{NO}_{2}\right.$, $\mathrm{NO}_{x}, \mathrm{CO}, \mathrm{C}_{6} \mathrm{H}_{6}$ and/or $\mathrm{O}_{3}$ ) and wind speed were analysed along with the modelled values of mixing-layer height for the location of those stations during the corresponding period.

Studies assessing the impact of selected meteorological parameters on air quality for other large Polish cities are known [5, 6, 8, 21, 33, 45], but the subjected area was usually characterized by a more favourable location with better ventilation properties. Similar analysis was also carried out several times for the city of Krakow [7, 25, 31], but for the earlier period. In these studies the attention was drawn to the importance of meteorological parameters (including temperature, wind speed and/or synoptic situation) for the variability of some pollutant concentrations and to significant difference in the nature of the relationship between these concentrations and meteorological parameters. In [25] it was proved that mixing-layer height had a significant impact on air pollution in 2012 in Krakow.

\section{Materials and methods}

The analysis was conducted for the results of continuous measurements of pollutant concentrations in the air carried out in 2014 and 2015 at two of the air quality monitoring stations belonging to the Voivodeship Inspectorate of Environmental Protection (WIOS) in Krakow [42]: Nowa Huta industrial station and Kurdwanow urban background station (Table 1, Figure 1), where during the period mentioned above some of meteorological parameters (including wind speed) were recorded concurrently. Measurements at the stations are performed using reference methods specified in the law individually for each substance [34].

The Nowa Huta station measures the impact of the nearby industrial facilities (situated along the dominant wind directions) and other emission sources, including: 
- an industrial complex (steel mill with heat and power plant, coke plant, rolling mills, foundries and cement plant) located at a distance of approx. $2.0-4.5 \mathrm{~km}$ to the east and northeast,

- a coal-fired combined heat and power plant located in a distance of approx. 3.6-3.8 $\mathrm{km}$ to the southwest,

- local road transport (approx. 30-35 $\mathrm{m}$ to the nearby street, $90-100 \mathrm{~m}$ to the busy junction),

- a fuel station located approx. $60 \mathrm{~m}$ toward the southwest,

- single individually heated buildings in the distance of approx. 75-300 $\mathrm{m}$ to the south and southeast,

- residential areas of single-family detached houses located at a distance of approx. $0.5-1.2 \mathrm{~km}$ to the south, and $1.0-1.5 \mathrm{~km}$ to the southeast.

Table 1. Description of the analysed WIOS air quality monitoring stations in Krakow (based on [3])

\begin{tabular}{|l|c|c|}
\hline \multicolumn{1}{|c|}{ Parameter } & Nowa Huta station & Kurdwanow station \\
\hline Country code & MpKrakBulwar & MpKrakBujaka \\
\hline International code & PL0039A & PL0501A \\
\hline Zone & \multicolumn{2}{|c|}{ Krakow agglomeration } \\
\hline Station name/address & Krakow, Bulwarowa St. & Krakow, Bujaka St. \\
\hline Location coordinates & $\Phi 50.069308$ & $\Phi 50.010575$ \\
(WGS84) & $\lambda 20.053492$ & $\lambda 19.949189$ \\
\hline Altitude & 195 m a.s.l. & 223 m a.s.l. \\
\hline Station type & industrial & urban background \\
\hline Substances measured & $\mathrm{PM}_{10}, \mathrm{PM}_{2.5}, \mathrm{SO}_{2}$, & $\mathrm{PM}_{10}, \mathrm{PM}_{2.5}, \mathrm{SO}_{2}$, \\
continuously $*$ & $\mathrm{NO}_{2}, \mathrm{NO}_{\mathrm{x}}, \mathrm{CO}, \mathrm{C}_{6} \mathrm{H}_{6}$ & $\mathrm{NO}_{\mathrm{x}}, \mathrm{O}_{3}$ \\
\hline
\end{tabular}

* automatic 1-h measurements

The Kurdwanow station measures typical urban background related to the impact of:

- low emission sources (local road traffic, the motorway bypass located at a distance of approx. 1.1-1.2 km to the south, single-family detached houses located in a distance of approx. $0.2-0.9 \mathrm{~km}$ to the north and northwest, compact residential area with individually heated houses situated in a distance of approx. 0.9-1.2 km to the north and approx. $1-2 \mathrm{~km}$ to the northwest, southwest and east),

- high point sources (two large combustion plants located approx. $11 \mathrm{~km}$ to the southwest and approx. $6 \mathrm{~km}$ to the northeast). 


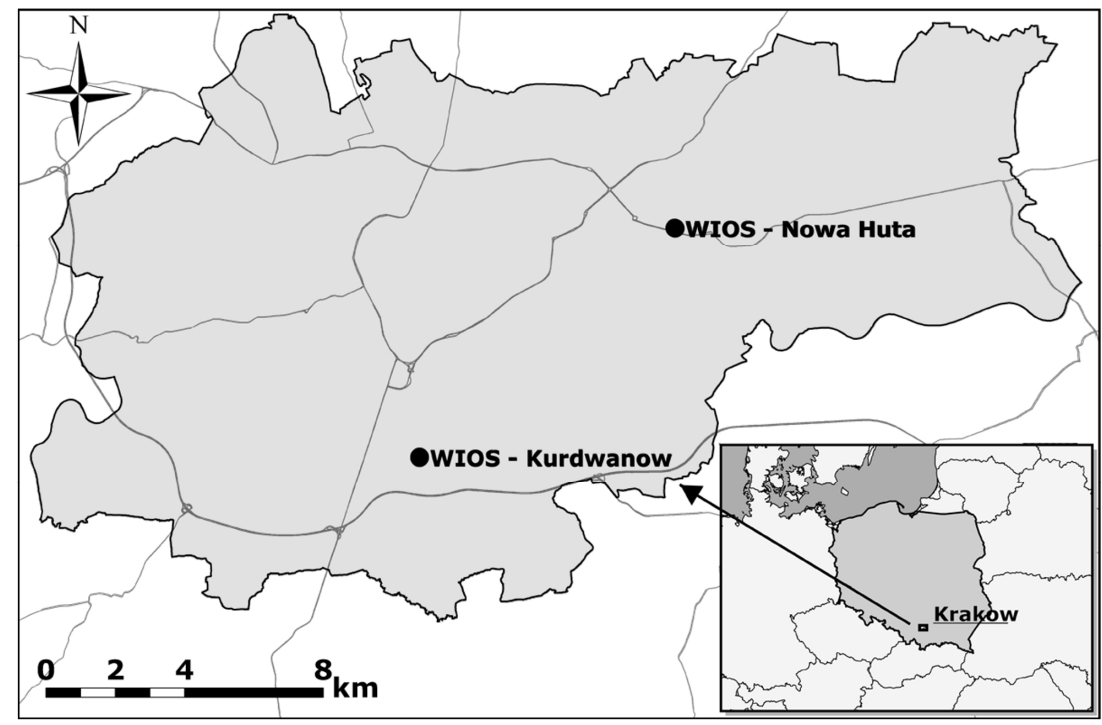

Fig. 1. Location of the analysed WIOS air quality monitoring stations in Krakow

Due to the lack of the mixing-layer height measurements in the area of the analysed air quality monitoring stations, its values were estimated using CALMET model [36]. Input measurement data for the CALMET model were obtained from two upper air stations (Wroclaw and Legionowo) and six surface meteorological stations (Krakow - Balice, Krakow - AGH, Bielsko-Biala, Katowice, Nowy Sacz, Tarnow). These data were derived from National Climatic Data Center (NCDC) [21] and NOAA Earth System Research Laboratory (ESRL) [23] databases, as well as from the METEO Service belonging to AGH, Faculty of Physics and Applied Computer Science [43]. Location of the used meteorological stations is shown in Figure 2.

Gridded geophysical data prepared on the basis of SRTM3 and Corine Land Cover database with a resolution of $200 \mathrm{~m}$ according to the methodology described in [26] and [27], were used for the calculation of three-dimensional meteorological data.

Depending on the case, the strength of correlation between measured parameters was determined using nonparametric Spearman's rank correlation coefficient $\left(r_{s}\right)$ at the significance level of $p<0.05$, Pearson correlation coefficient $(r)$ and/or coefficient of determination $\left(r^{2}\right)$. Analysis was carried out with diversity occurring in different months of the year taken into account. 


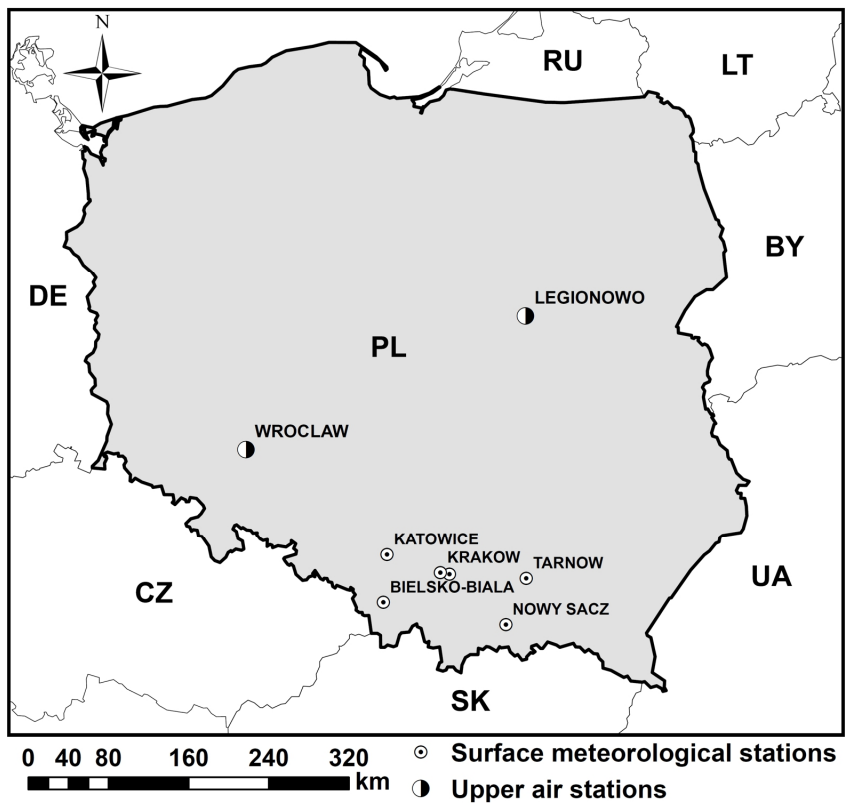

Fig. 2. Location of the meteorological stations used for calculations of mixing-layer height in the area of air quality monitoring points in Krakow

\section{Results and discussion}

\subsection{The impact of wind speed}

In the case of most substances measured continuously at the analysed air quality monitoring stations an exponential relationship between concentration in the air and wind speed was observed. This relationship is particularly evident in the winter months (Figures 3 and 4). For this reason, the strength of the correlation for the analysed parameters was determined using the Spearman's rank correlation coefficient $\left(r_{s}\right)$ with differences during particular periods of the year taken into account. Calculated correlation coefficients $r_{s}$ (at the significance level of $p<0.05$ ) obtained for each measuring station are presented in the Tables 2 and 3 (monthly and annual values) and Figure 5 (for heating and non-heating season).

Based on the calculated correlation coefficients $r_{s}$ it can be concluded, that the concentrations of $\mathrm{PM}_{10}, \mathrm{PM}_{2.5}, \mathrm{NO}_{\mathrm{x}}, \mathrm{CO}$ and $\mathrm{C}_{6} \mathrm{H}_{6}$ in the air (and for the Kurdwanow station $\mathrm{NO}_{2}$ as well) generally decrease with increasing wind speed $\left(r_{s}<0\right)$, with the greatest absolute values of correlation coefficients obtained for the winter months. The strongest inverse relationship, in particular during the heating season was found for $\mathrm{PM}_{10}, \mathrm{PM}_{2.5}$ and $\mathrm{CO}$. Important sources of their emission are household fuel combustion and automotive vehicles. For those substances analysed correlation coefficient throughout the heating season for the 
Nowa Huta station reaches the value of $\left|r_{s}\right|>0.6$ (Figure 5), and in some winter months the value of $\left|r_{s}\right|$ exceeds 0.7 (Table 2).

This indicates a significant influence of low wind speed episodes on deterioration of aerosanitary conditions in Krakow agglomeration in the heating season. During that period, wind speed is seemed to be of fundamental importance in shaping the levels of pollutants in the air, and with the limited possibilities of air masses vertical movements it can strongly determine the presence of exceedances of $\mathrm{PM}_{10}$ and $\mathrm{PM}_{2.5}$ concentrations in the air of Krakow.
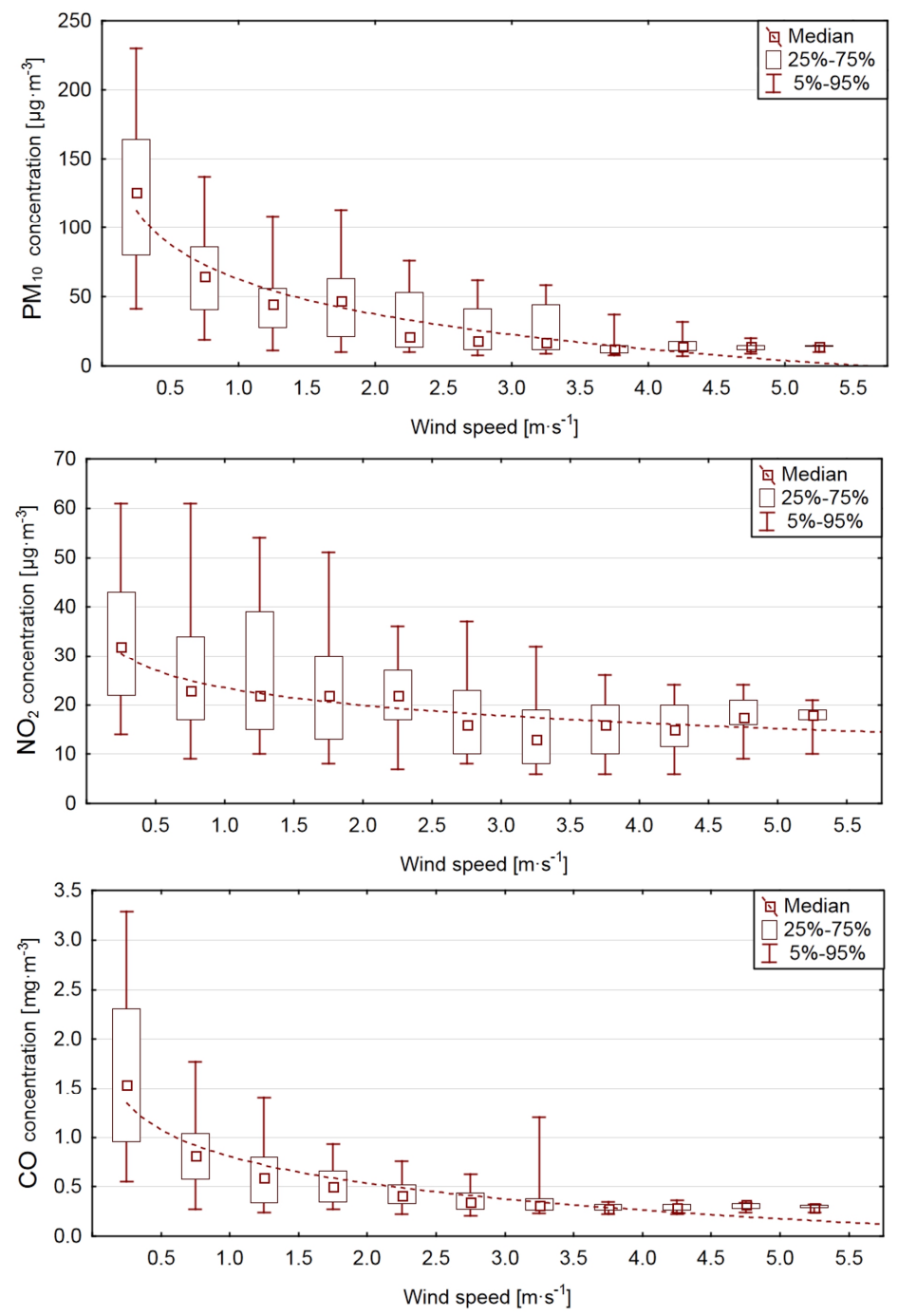

Fig. 3. Scatter plots of 1-hour concentrations of $\mathrm{PM}_{10}, \mathrm{NO}_{2}$ and $\mathrm{CO}$ aggregated relatively to wind speed values for the Nowa Huta station in December 2014 

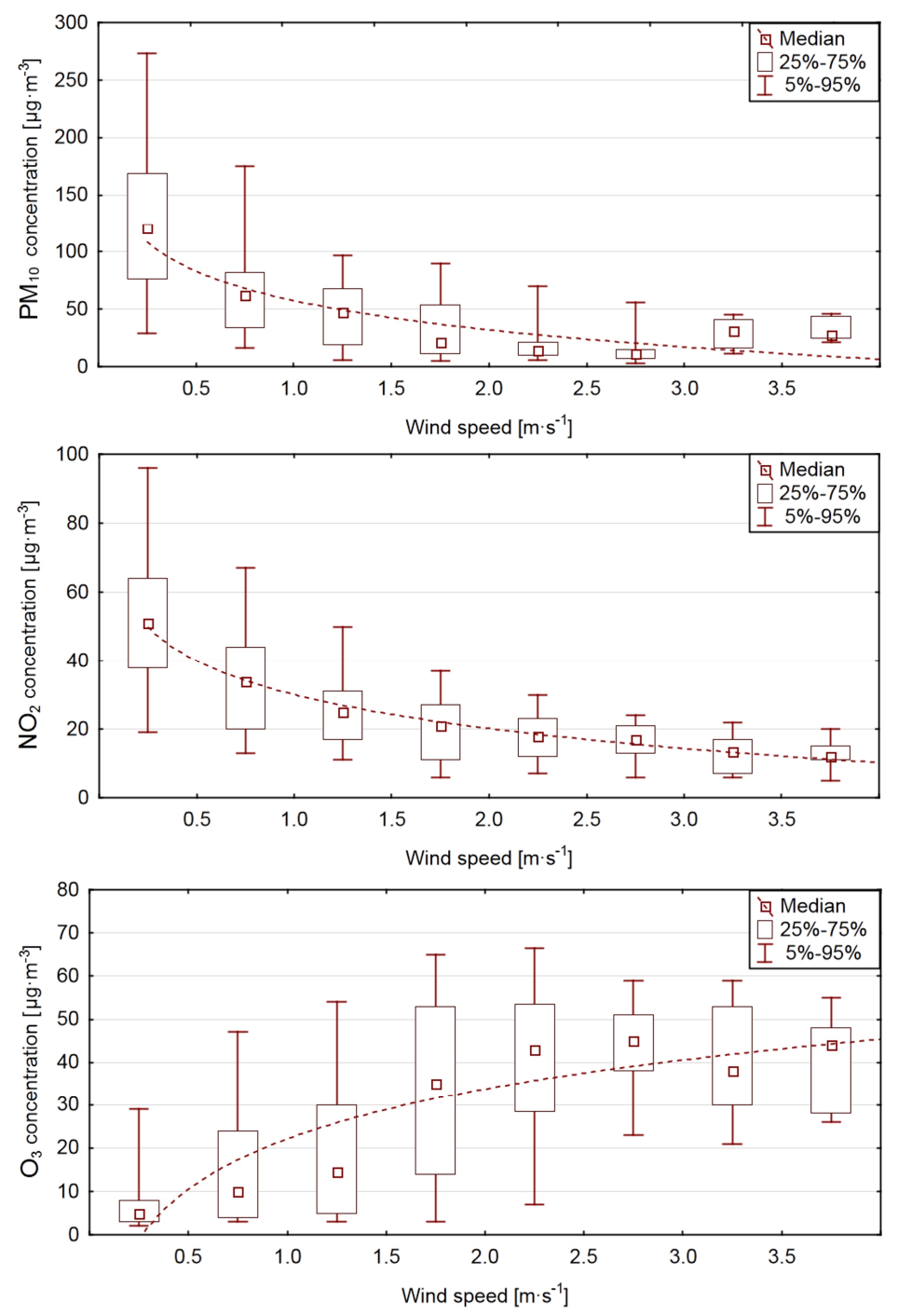

Fig. 4. Scatter plots of 1-hour concentrations of $\mathrm{PM}_{10}, \mathrm{NO}_{2}$ and $\mathrm{O}_{3}$ aggregated relatively to wind speed values for the Kurdwanow station in December 2014

During the analysed period (2014-2015) in the area of the analysed air quality monitoring stations the calm and weak wind episodes (wind speed up to $1 \mathrm{~m} \cdot \mathrm{s}^{-1}$ ) were predominant, which constitute, depending on the station and year, approx. 50-64\% of all observations and reflects a typical situation for the city of Krakow [25]. The monthly averaged wind speeds, depending on the month and the station, changed in the range of 0.5 to $1.6 \mathrm{~m} \cdot \mathrm{s}^{-1}$ irrespective of the season. At the Kurdwanow station they were approx. $22 \%$ lower compared to the Nowa 
Huta station. This may be the one of the reasons for higher $\mathrm{NO}_{2}$ and $\mathrm{NO}_{\mathrm{x}}$ concentrations in the air during 2014-2015 in the area of the Kurdwanow station compared to the Nowa Huta station (16\% and $38 \%$, respectively) [3, 42].

Table 2. The Spearman's rank correlation coefficient values between hourly averaged pollutant concentrations and wind speed for the Nowa Huta station in 2014-2015 $(p<0.05)$

\begin{tabular}{|c|c|c|c|c|c|c|c|c|}
\hline Year & Month & $\mathbf{P M}_{10}$ & $\mathbf{P M}_{2,5}$ & $\mathrm{SO}_{2}$ & $\mathrm{NO}_{2}$ & $\mathbf{N O}_{\mathrm{x}}$ & $\mathrm{CO}$ & $\mathbf{C}_{6} \mathbf{H}_{6}$ \\
\hline \multirow{13}{*}{ 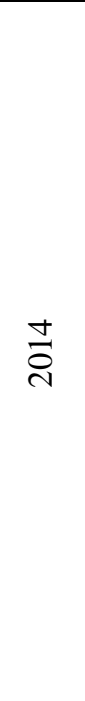 } & 1 & -0.742 & -0.734 & 0.258 & -0.560 & -0.717 & -0.538 & -0.628 \\
\hline & 2 & -0.694 & -0.687 & 0.290 & -0.316 & -0.614 & -0.675 & -0.392 \\
\hline & 3 & -0.689 & -0.681 & 0.183 & -0.506 & -0.555 & -0.653 & -0.418 \\
\hline & 4 & -0.332 & -0.383 & 0.474 & -0.326 & -0.437 & -0.437 & -0.297 \\
\hline & 5 & -0.475 & -0.556 & 0.208 & -0.419 & -0.456 & -0.521 & -0.410 \\
\hline & 6 & -0.490 & -0.489 & 0.230 & -0.110 & -0.219 & -0.388 & -0.209 \\
\hline & 7 & -0.405 & -0.464 & 0.290 & -0.379 & -0.399 & -0.441 & -0.164 \\
\hline & 8 & -0.477 & -0.508 & 0.524 & $0.059 *$ & -0.102 & -0.401 & $-0.065 *$ \\
\hline & 9 & -0.268 & -0.324 & 0.240 & -0.229 & -0.461 & -0.331 & -0.116 \\
\hline & 10 & -0.636 & -0.628 & -0.326 & -0.101 & -0.491 & -0.658 & -0.397 \\
\hline & 11 & -0.400 & -0.373 & -0.211 & -0.104 & -0.499 & -0.529 & -0.383 \\
\hline & 12 & -0.749 & -0.759 & -0.233 & -0.453 & -0.584 & -0.745 & -0.715 \\
\hline & $1-12$ & -0.352 & -0.338 & 0.213 & -0.264 & -0.448 & -0.447 & -0.295 \\
\hline \multirow{13}{*}{$\frac{n}{i}$} & 1 & -0.712 & -0.692 & $0.070 *$ & -0.410 & -0.485 & -0.705 & -0.651 \\
\hline & 2 & -0.583 & -0.581 & $0.064 *$ & -0.384 & -0.582 & -0.634 & -0.566 \\
\hline & 3 & -0.560 & -0.572 & 0.247 & -0.418 & -0.483 & -0.571 & -0.507 \\
\hline & 4 & -0.513 & -0.543 & 0.136 & -0.317 & -0.293 & -0.291 & -0.547 \\
\hline & 5 & -0.410 & -0.465 & 0.164 & -0.311 & -0.356 & -0.409 & -0.352 \\
\hline & 6 & -0.393 & -0.673 & 0.195 & -0.475 & -0.499 & -0.406 & -0.483 \\
\hline & 7 & \multirow{2}{*}{\multicolumn{7}{|c|}{ wind speed measurements unavailable }} \\
\hline & 8 & & & & & & & \\
\hline & 9 & -0.267 & -0.322 & $0.087 *$ & $0.057 *$ & -0.173 & -0.262 & -0.191 \\
\hline & 10 & -0.311 & -0.433 & 0.432 & $0.000^{*}$ & -0.487 & -0.542 & -0.511 \\
\hline & 11 & -0.717 & -0.720 & 0.311 & -0.228 & -0.593 & -0.755 & -0.741 \\
\hline & 12 & -0.698 & -0.695 & 0.206 & -0.271 & -0.573 & -0.688 & -0.655 \\
\hline & $1-12$ & -0.478 & -0.475 & 0.242 & -0.277 & -0.441 & -0.472 & -0.465 \\
\hline
\end{tabular}

* statistically insignificant value 
Table 3. The Spearman's rank correlation coefficient values between hourly averaged pollutant concentrations and wind speed for the Kurdwanow station in 2014-2015 $(p<0.05)$

\begin{tabular}{|c|c|c|c|c|c|c|c|}
\hline Year & Month & $\mathbf{P M}_{10}$ & $\mathbf{P M}_{2.5}$ & $\mathrm{SO}_{2}$ & $\mathrm{NO}_{2}$ & $\mathbf{N O}_{\mathbf{x}}$ & $\mathbf{O}_{3}$ \\
\hline \multirow{13}{*}{$\stackrel{\Delta}{\stackrel{\sim}{~}}$} & 1 & -0.593 & -0.599 & -0.159 & -0.640 & -0.720 & 0.571 \\
\hline & 2 & -0.386 & -0.337 & -0.351 & -0.542 & -0.568 & 0.237 \\
\hline & 3 & -0.661 & -0.651 & -0.571 & -0.714 & -0.720 & 0.637 \\
\hline & 4 & -0.441 & -0.489 & -0.096 & -0.705 & -0.754 & 0.783 \\
\hline & 5 & -0.447 & -0.466 & $-0.068^{*}$ & -0.708 & -0.723 & 0.657 \\
\hline & 6 & -0.525 & -0.497 & $-0.049^{*}$ & -0.636 & -0.679 & 0.598 \\
\hline & 7 & -0.255 & -0.318 & -0.331 & -0.695 & -0.731 & 0.667 \\
\hline & 8 & -0.336 & -0.406 & -0.329 & -0.552 & -0.607 & 0.693 \\
\hline & 9 & -0.280 & -0.349 & -0.649 & -0.682 & -0.806 & 0.702 \\
\hline & 10 & -0.477 & -0.450 & -0.399 & -0.556 & -0.733 & 0.677 \\
\hline & 11 & -0.437 & -0.367 & -0.317 & -0.632 & -0.761 & 0.470 \\
\hline & 12 & -0.685 & -0.682 & -0.691 & -0.685 & -0.724 & 0.637 \\
\hline & $1-12$ & -0.419 & -0.427 & -0.202 & -0.522 & -0.532 & 0.627 \\
\hline \multirow{13}{*}{$\frac{n}{\stackrel{i}{d}}$} & 1 & -0.644 & -0.682 & -0.546 & -0.606 & -0.636 & 0.612 \\
\hline & 2 & -0.550 & -0.550 & -0.407 & -0.679 & -0.774 & 0.745 \\
\hline & 3 & -0.604 & -0.574 & -0.579 & -0.714 & -0.740 & 0.705 \\
\hline & 4 & -0.584 & -0.608 & -0.283 & -0.616 & -0.587 & 0.640 \\
\hline & 5 & -0.520 & -0.571 & -0.180 & -0.620 & -0.663 & 0.633 \\
\hline & 6 & -0.153 & -0.394 & -0.325 & -0.687 & -0.717 & 0.703 \\
\hline & 7 & -0.341 & -0.482 & -0.143 & -0.695 & -0.670 & 0.607 \\
\hline & 8 & -0.227 & -0.352 & -0.132 & -0.743 & -0.795 & 0.683 \\
\hline & 9 & -0.437 & -0.511 & -0.247 & -0.587 & -0.675 & 0.675 \\
\hline & 10 & -0.428 & -0.429 & -0.366 & -0.608 & -0.789 & 0.699 \\
\hline & 11 & -0.675 & -0.688 & -0.442 & -0.566 & -0.721 & 0.699 \\
\hline & 12 & -0.634 & -0.635 & -0.423 & -0.622 & -0.754 & 0.635 \\
\hline & $1-12$ & -0.444 & -0.518 & -0.224 & -0.529 & -0.533 & 0.631 \\
\hline
\end{tabular}

* statistically insignificant value

Considerably higher concentrations of $\mathrm{NO}_{\mathrm{x}}$ recorded at the Kurdwanow station may also indicate that it is subjected to greater emissions from the road traffic and industrial facilities (e.g. large combustion plants) than the Nowa Huta station, especially since the differences mentioned above occur throughout the year. On the other hand, increased wind speed may also accelerate the oxidation 
of $\mathrm{NO}$ to $\mathrm{NO}_{2}$, as a result of the inflow of larger amounts of oxidants (including ozone and radicals) and catalysts (hydrocarbons) for the process from other areas [2]. This may partially account for the weaker negative correlation between $\mathrm{NO}_{2}$ and wind speed observed at the Nowa Huta station and for smaller annually averaged $\mathrm{NO}_{\mathrm{x}} / \mathrm{NO}_{2}$ ratio in the analysed period (at the level of 2.3) compared to the Kurdwanow station (equal to 2.7).

a)

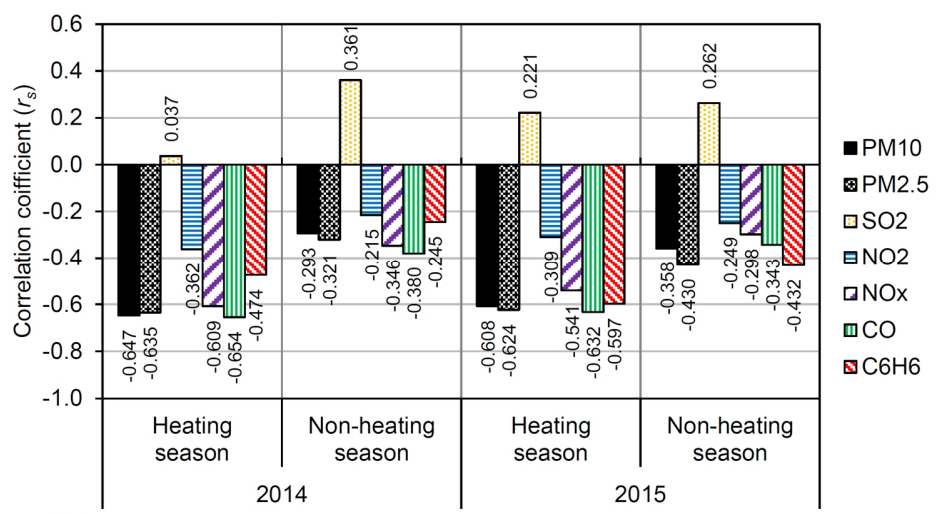

b)

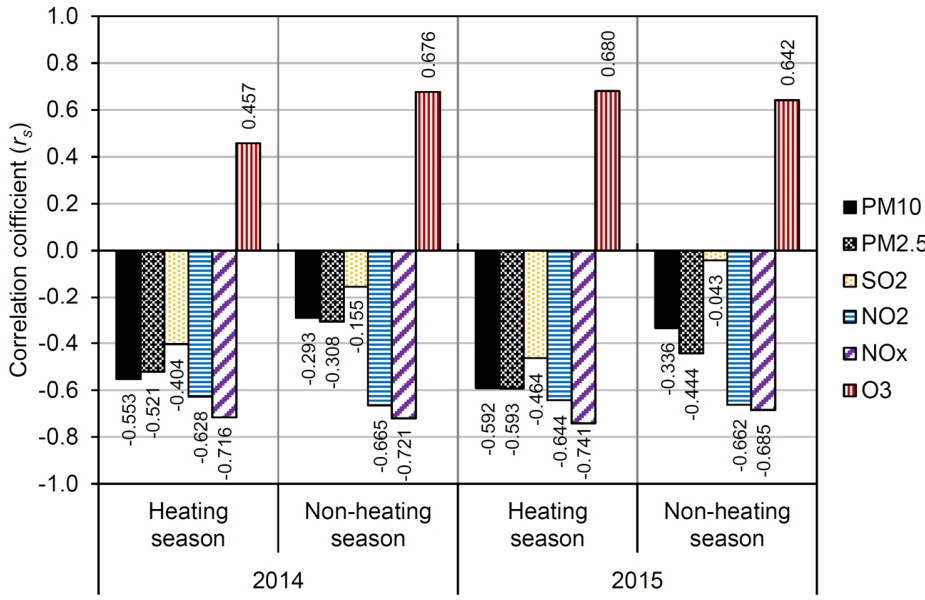

Fig. 5. Spearman's rank correlation coefficients $\left(r_{s}\right)$ for hourly averaged pollutant concentrations in relation to wind speed at the Nowa Huta station (a) and the Kurdwanow station (b) in the heating (I-III and X-XII) and non-heating season (IV-IX) for 2014 and $2015(p<0.05)$

In the case of $\mathrm{SO}_{2}$, the positive correlation coefficient in relation to wind speed obtained for the Nowa Huta station appears to be caused by the inflow of this substance from other parts of Krakow and neighbouring municipalities with dense detached housing, and by accelerated transportation of this pollutant from more distant industrial emission sources. It is important to emphasize that $\mathrm{SO}_{2}$ concentration in the air is strongly associated with other meteorological parame- 
ters (including relative humidity and air temperature), which under specific conditions with availability of adequate amounts of metal compounds (promoting conversion of $\mathrm{SO}_{2}$ to $\mathrm{SO}_{3}$ ) and ammonia, contribute to the secondary inorganic aerosols formation (mainly to ammonium sulphate). The intensification of this process can be particularly observed at night, when the water vapour contained in the air turns into liquid phase. This may cause further weakening of correlation between $\mathrm{SO}_{2}$ and wind speed.

For the Kurdwanow station significantly positive correlation between $\mathrm{O}_{3}$ concentrations in the air and wind speed was obtained. The reason behind this may be associated with more intense inflow of air rich in $\mathrm{NO}_{2}$ and $\mathrm{O}_{3}$ at high wind speeds (e.g. from less urban, wooded and rural areas characterized by higher molar ratio of $\mathrm{NMVOCs} / \mathrm{NO}_{\mathrm{x}}$ in the air than in urban areas). This occurrence is possible to take place mainly during hot season together with adequately high insolation. On the other hand, it is possible for NO to be blown away from urban areas, which otherwise, after being emitted from local sources (e.g. road transport) and, could react with $\mathrm{O}_{3}$ and consequently reduce its concentration in the air. This situation is always present, but may be of particular importance at low insolation (winter, clouded sky etc.). During these conditions, formed $\mathrm{NO}_{2}$ is not able to undergo photodissociation, and thus, the recreation of $\mathrm{O}_{3}$ is impossible. Simultaneously, wind can change the state of equilibrium between $\mathrm{NO}-\mathrm{NO}_{2}-\mathrm{O}_{3}$ concentrations by stripping away the air abundant in $\mathrm{NO}$ from the analysed area and inflowing over this area the air richer in oxidising substances (including radicals $\mathrm{HO}^{*}, \mathrm{HO}_{2} *, \mathrm{O}^{*}$ or organic radicals, etc.).

Given the Figures 3 and 4 it may be concluded, that reduction in air concentrations of some pollutants with the increase of wind speed cannot be observed beyond a predetermined point. Ventilation of the region affects the level of dilution of the substance, which is however limited by its background concentration present within the area (or within a given wind rose sector).

At high wind speeds during dry period, concentration of particulate matter in the air can possibly increase again, which may consequently weaken the negative nature of the relationship between these parameters. Explanation of this phenomenon is associated with wind erosion and the entrainment of dust from the ground including the roads (fugitive dust emission), which occur at high wind speeds. However, the frequency of higher wind speed episodes in the area of analysed monitoring stations is usually very low. For example, in 2014 for the Nowa Huta and Kurdwanow stations those episodes accounted for 4.0 and $1.7 \%$ (wind speed above $3 \mathrm{~m} \cdot \mathrm{s}^{-1}$ ) and 0.7 and $0.1 \%$ (wind speed above $4 \mathrm{~m} \cdot \mathrm{s}^{-1}$ ) in relation to all observations with maximum of hourly averaged wind speed equal to 5.3 and $4.4 \mathrm{~m} \cdot \mathrm{s}^{-1}$, respectively. 


\subsection{The impact of mixing-layer height}

Cyclic changes in the height (depth) of mixing layer, which characterizes the range and intensity of air masses vertical movements, are responsible for significant daily variation of air pollutant concentrations in Krakow. This height may vary from tens of meters in case of surface-based temperature inversion (at night) to more than $1000 \mathrm{~m}$ in situation with strong vertical movements of thermodynamic origin (convection), primarily occurring in the daytime. The most unfavourable conditions appear to be connected with high-pressure situations, low horizontal pressure gradient and the temperature distribution during inversion (sometimes throughout the day), which result in a significant deterioration of dispersion properties of air pollutants [33, 40].

Figure 6 shows the monthly averaged variability of mixing-layer height, calculated for the location area of the analysed air quality monitoring stations. It reveals that this parameter is also subjected to significant fluctuations during the year with lowest values in the cold months.

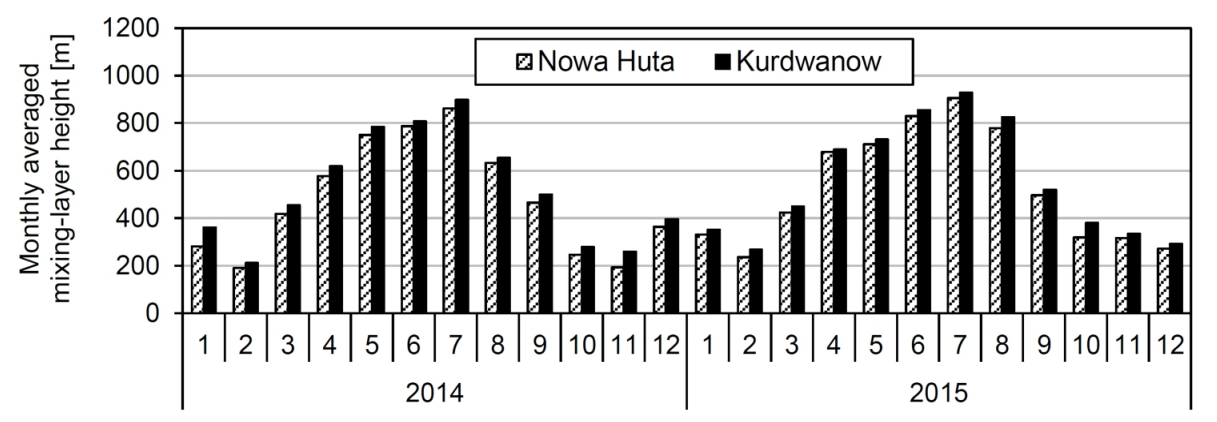

Fig. 6. The variability of the monthly averaged mixing-layer height for the location area of the analysed air quality monitoring stations in Krakow (modelling results)

The Spearman's rank correlation coefficients obtained for each of the stations between modelled 1-hour averaged mixing-layer height and measured concentrations of pollutants are presented in Tables 4 and 5 (monthly and annual) and Figure 7 (divided into heating and non-heating season).

Similarly to the results of the wind speed impact assessment, the $\mathrm{PM}_{10}$, $\mathrm{PM}_{2.5}, \mathrm{NO}_{2}, \mathrm{NO}_{\mathrm{x}}, \mathrm{CO}$ and $\mathrm{C}_{6} \mathrm{H}_{6}$ concentrations in the air decrease with increasing mixing-layer height, especially in the winter months (for the $\mathrm{NO}_{2}$ and $\mathrm{NO}_{\mathrm{x}}$ concentrations measured at the Nowa Huta station, this correlation is weaker). For $\mathrm{SO}_{2}$ concentrations a weak positive correlation in relation to the mixinglayer height was found for the measurements from the Nowa Huta station, and a weak negative correlation during the heating season with no correlation in the non-heating season for measurements at the Kurdwanow station (Figure 7). 
Table 4. The Spearman's rank correlation coefficient values between hourly averaged pollutant concentrations and mixing-layer height for the Nowa Huta station in 2014-2015 $(p<0.05)$

\begin{tabular}{|c|c|c|c|c|c|c|c|c|}
\hline Year & Month & $\mathbf{P M}_{10}$ & $\mathbf{P M}_{2.5}$ & $\mathrm{SO}_{2}$ & $\mathrm{NO}_{2}$ & $\mathbf{N O}_{\mathbf{x}}$ & $\mathrm{CO}$ & $\mathrm{C}_{6} \mathrm{H}_{6}$ \\
\hline \multirow{13}{*}{ 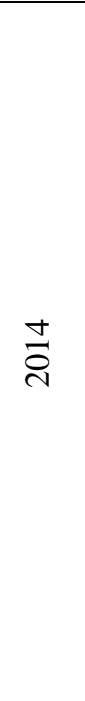 } & 1 & -0.636 & -0.651 & 0.249 & -0.424 & -0.540 & -0.461 & -0.531 \\
\hline & 2 & -0.467 & -0.492 & 0.265 & -0.171 & -0.319 & -0.457 & -0.237 \\
\hline & 3 & -0.573 & -0.604 & 0.242 & -0.418 & -0.422 & -0.618 & -0.315 \\
\hline & 4 & -0.334 & -0.422 & 0.395 & -0.297 & -0.296 & -0.465 & -0.220 \\
\hline & 5 & -0.363 & -0.523 & 0.246 & -0.370 & -0.357 & -0.477 & -0.353 \\
\hline & 6 & -0.382 & -0.531 & 0.264 & -0.261 & -0.343 & -0.457 & -0.446 \\
\hline & 7 & -0.367 & -0.529 & 0.235 & -0.227 & -0.246 & -0.388 & -0.168 \\
\hline & 8 & -0.481 & -0.592 & 0.531 & $-0.064 *$ & -0.150 & -0.469 & -0.090 \\
\hline & 9 & -0.286 & -0.384 & 0.235 & -0.083 & -0.212 & -0.393 & -0.116 \\
\hline & 10 & -0.442 & -0.478 & -0.169 & -0.127 & -0.342 & -0.468 & -0.234 \\
\hline & 11 & -0.236 & -0.246 & -0.100 & $-0.067 *$ & -0.308 & -0.340 & -0.199 \\
\hline & 12 & -0.725 & -0.734 & -0.222 & -0.392 & -0.480 & -0.693 & -0.699 \\
\hline & $1-12$ & -0.449 & -0.497 & 0.072 & -0.262 & -0.351 & -0.491 & -0.342 \\
\hline \multirow{13}{*}{$\frac{n}{\stackrel{\nu}{~}}$} & 1 & -0.637 & -0.641 & 0.117 & -0.261 & -0.286 & -0.627 & -0.615 \\
\hline & 2 & -0.508 & -0.523 & 0.185 & -0.325 & -0.417 & -0.520 & -0.486 \\
\hline & 3 & -0.546 & -0.565 & 0.315 & -0.375 & -0.371 & -0.455 & -0.594 \\
\hline & 4 & -0.417 & -0.563 & 0.159 & -0.306 & -0.244 & -0.307 & -0.594 \\
\hline & 5 & -0.313 & -0.467 & 0.384 & -0.244 & -0.242 & -0.259 & -0.356 \\
\hline & 6 & -0.242 & -0.406 & 0.289 & -0.317 & -0.261 & -0.352 & -0.375 \\
\hline & 7 & -0.229 & -0.492 & 0.425 & -0.156 & -0.134 & -0.462 & -0.288 \\
\hline & 8 & -0.259 & -0.415 & 0.387 & -0.455 & -0.487 & -0.474 & -0.415 \\
\hline & 9 & -0.422 & -0.485 & 0.277 & -0.236 & -0.268 & -0.410 & -0.379 \\
\hline & 10 & -0.364 & -0.468 & 0.532 & $-0.003^{*}$ & -0.288 & -0.504 & -0.509 \\
\hline & 11 & -0.618 & -0.637 & 0.279 & -0.105 & -0.362 & -0.598 & -0.643 \\
\hline & 12 & -0.616 & -0.632 & 0.254 & -0.144 & -0.362 & -0.555 & -0.610 \\
\hline & $1-12$ & -0.444 & -0.511 & 0.207 & -0.278 & -0.335 & -0.459 & -0.489 \\
\hline
\end{tabular}

* statistically insignificant value

The concentration of $\mathrm{O}_{3}$ (measured only at the Kurdwanow station) increases with the increase in mixing-layer height. It is important to highlight the following facts related to the formation of ozone: 
- mixing-layer is the deeper the higher isolation level which causes the increase of temperature and intensification of updrafts and these conditions are always favourable to the formation of $\mathrm{O}_{3}$ and conversion of $\mathrm{SO}_{2}$ to $\mathrm{SO}_{3}$,

- increase in the mixing-layer height is related to a strong convection, which promotes mixing of the pollutants and improves the kinetics of the $\mathrm{NO}$ to $\mathrm{NO}_{2}$ conversion - and consequently the kinetics of the formation of $\mathrm{O}_{3}$ and oxidation of $\mathrm{SO}_{2}$ to $\mathrm{SO}_{3}$ as well,

- increase in the mixing-layer height in urban areas (heat island) always drags in from surrounding areas the air rich in hydrocarbons, and oxidation of hydrocarbons is the source of radicals significantly accelerating the conversion of $\mathrm{NO}$ to $\mathrm{NO}_{2}$, hence shifting the photostationary equilibrium between $\mathrm{NO}-\mathrm{NO}_{2}-$ $\mathrm{O}_{3}$ toward the production of $\mathrm{O}_{3}$ and organic peroxides (including PAN).

In existing atmosphere all of these phenomena occur depending on the complexity of meteorological conditions and the composition of atmosphere determined by characteristics of emission sources.

In general, the increase in height of mixing layer causes similar effects as the increase in wind speed. However, the mixing-layer height remains in a slightly weaker correlation with the concentrations of most substances (excluding $\mathrm{O}_{3}$ ) compared to the results for the wind speed, both in the heating and nonheating season. This may be partially due to the fact, that the height of mixing layer was determined using mathematical modelling with CALMET model, based on the datasets derived from measuring stations located at a great distance from the city of Krakow. Existing studies show that the CALMET model may cause an overestimation of mixing-layer height maximum values and is characterized by a strong variability during the afternoon compared to the observed values [9]. Research conducted for the mixing-layer height measurement data indicates that this parameter may determine the concentration levels of pollutants in the air to much greater extent within the street canyon (in particular for the case of $\mathrm{PM}_{10}$ ) [39].

Similar impact on air quality of wind speed and mixing-layer height values results from the fact that these parameters are partially correlated with each other (especially in the winter months). Thus, their impact can be accumulated, affecting exponentially the variability of the pollutant concentrations within the air near to the surface in reference to only one of these parameters shown in Figure 3 and 4 and proved in [25], among others. Detailed analysis of this issue is presented in the next chapter.

\subsection{Cumulated impact of wind speed and mixing-layer height}

The Pearson correlation coefficients between mixing-layer height and wind speed obtained for both of the stations in the period of 2014-2015 amounted to 0.62 during the heating season and 0.40 in the non-heating season (Table 6). The highest value of Pearson's linear correlation coeffi- 
cient $(r>0.83)$ with coefficient of determination at $r^{2} \cong 0.7$ was obtained for analysed data in December 2014 (Figure 8).

Table 5. The Spearman's rank correlation coefficient values between hourly averaged pollutant concentrations and mixing-layer height for the Kurdwanow station in 2014-2015 $(p<0.05)$

\begin{tabular}{|c|c|c|c|c|c|c|c|}
\hline Year & Month & $\mathrm{PM}_{10}$ & $\mathbf{P M}_{2,5}$ & $\mathrm{SO}_{2}$ & $\mathrm{NO}_{2}$ & $\mathbf{N O}_{\mathbf{x}}$ & $\mathrm{O}_{3}$ \\
\hline \multirow{13}{*}{$\underset{⿱ 亠}{\stackrel{\Xi}{\Xi}}$} & 1 & -0.676 & -0.688 & -0.221 & -0.578 & -0.652 & 0.476 \\
\hline & 2 & -0.446 & -0.449 & -0.256 & -0.389 & -0.457 & 0.337 \\
\hline & 3 & -0.580 & -0.563 & -0.353 & -0.555 & -0.528 & 0.655 \\
\hline & 4 & -0.380 & -0.434 & $-0.027 *$ & -0.535 & -0.503 & 0.692 \\
\hline & 5 & -0.361 & -0.372 & $0.061 *$ & -0.581 & -0.545 & 0.674 \\
\hline & 6 & -0.296 & -0.324 & $0.040 *$ & -0.487 & -0.502 & 0.720 \\
\hline & 7 & -0.253 & -0.276 & -0.203 & -0.558 & -0.545 & 0.699 \\
\hline & 8 & -0.335 & -0.384 & -0.220 & -0.520 & -0.499 & 0.703 \\
\hline & 9 & -0.269 & -0.378 & -0.348 & -0.415 & -0.464 & 0.597 \\
\hline & 10 & -0.351 & -0.390 & -0.165 & -0.351 & -0.425 & 0.545 \\
\hline & 11 & -0.339 & -0.323 & -0.270 & -0.445 & -0.507 & 0.454 \\
\hline & 12 & -0.688 & -0.674 & -0.549 & -0.553 & -0.583 & 0.655 \\
\hline & $1-12$ & -0.419 & -0.427 & -0.202 & -0.522 & -0.532 & 0.627 \\
\hline \multirow{13}{*}{$\stackrel{n}{\stackrel{n}{c}}$} & 1 & -0.616 & -0.664 & -0.291 & -0.441 & -0.470 & 0.653 \\
\hline & 2 & -0.497 & -0.509 & -0.332 & -0.545 & -0.573 & 0.634 \\
\hline & 3 & -0.549 & -0.544 & -0.412 & -0.537 & -0.512 & 0.648 \\
\hline & 4 & -0.459 & -0.591 & -0.111 & -0.490 & -0.436 & 0.660 \\
\hline & 5 & -0.396 & -0.541 & 0.076 & -0.468 & -0.457 & 0.640 \\
\hline & 6 & -0.252 & -0.492 & $-0.001 *$ & -0.492 & -0.465 & 0.650 \\
\hline & 7 & -0.244 & -0.408 & $-0.001 *$ & -0.576 & -0.531 & 0.665 \\
\hline & 8 & -0.199 & -0.361 & $-0.070^{*}$ & -0.651 & -0.651 & 0.697 \\
\hline & 9 & -0.361 & -0.503 & -0.118 & -0.460 & -0.467 & 0.610 \\
\hline & 10 & -0.475 & -0.521 & -0.217 & -0.492 & -0.565 & 0.662 \\
\hline & 11 & -0.593 & -0.601 & -0.324 & -0.429 & -0.523 & 0.566 \\
\hline & 12 & -0.571 & -0.580 & -0.277 & -0.392 & -0.506 & 0.533 \\
\hline & $1-12$ & -0.444 & -0.518 & -0.224 & -0.529 & -0.533 & 0.631 \\
\hline
\end{tabular}

* statistically insignificant value 
a)

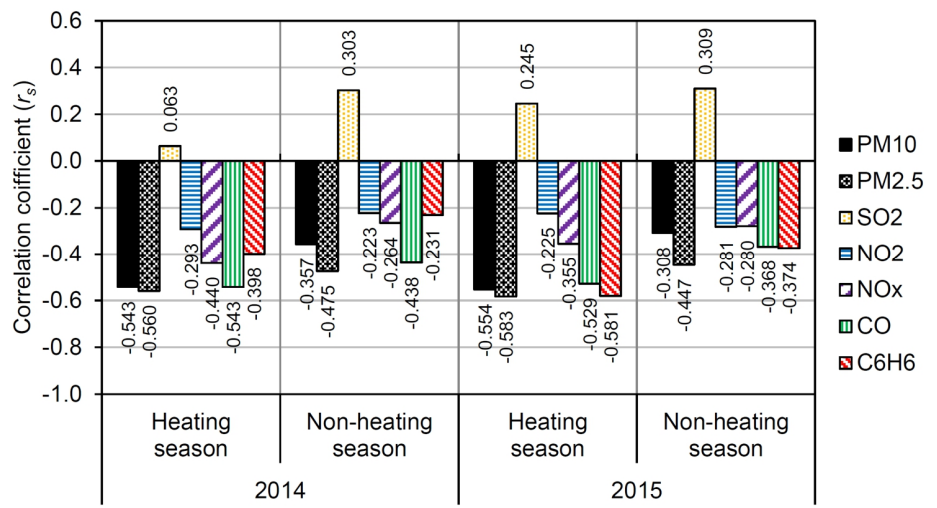

b)

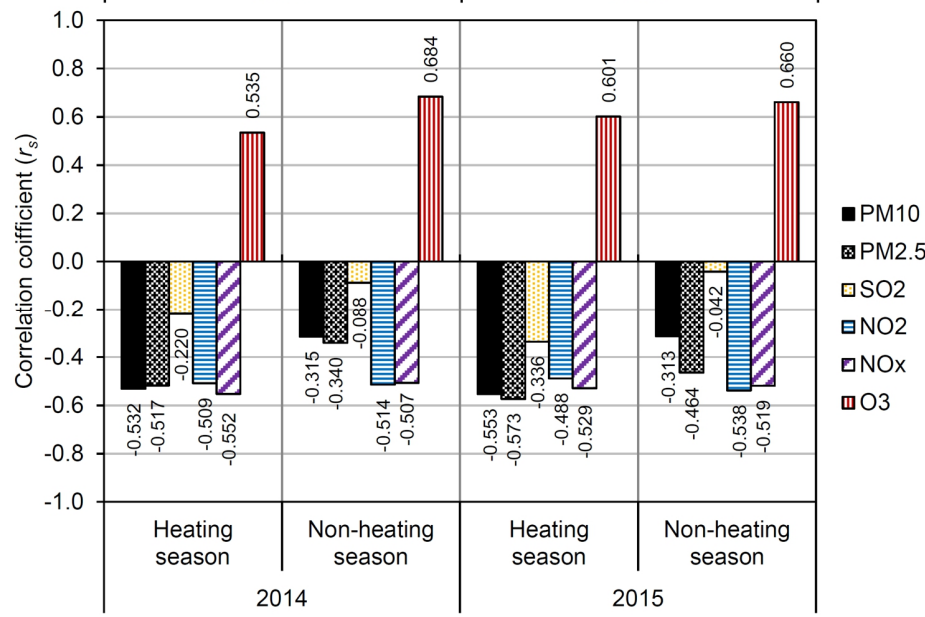

Fig. 7. Spearman's rank correlation coefficients $\left(r_{s}\right)$ for hourly averaged pollutants' concentrations in relation to mixing-layer height at the Nowa Huta station (a) and the Kurdwanow station (b) in the heating (I-III and X-XII) and non-heating season (IV-IX) for 2014 and $2015(p<0.05)$

In practice, rather strong relationship between wind speed and mixing-layer height present during several months of the year makes it impossible to conduct multivariate regression analysis, which provides for the determination of their simultaneous impact on the pollutant concentrations recorded at the monitoring stations. However, the cumulative effect of these parameters can be graphically presented, as an example of the $\mathrm{PM}_{10}$ concentrations in relation to wind speed and mixing-layer height values for the Nowa Huta and Kurdwanow stations during the heating season in 2014 shown in Figure 9.

Similar effects can also be observed for other substances, which concentrations in the air are significantly dependent on the variability of the parameters mentioned above. An exemplary episode associated with considerable reduction in initially high concentrations of certain air pollutants as a result of great in- 
crease in the wind speed and the height of mixing layer during the second half of December 2014 is shown in Figure 10 (Nowa Huta station) and Figure 11 (Kurdwanow station).

Table 6. Pearson correlation coefficients $(r)$ and coefficients of determination $\left(r^{2}\right)$ for wind speed and mixing-layer height obtained for the period of 2014-2015 in the area of analysed air quality monitoring stations $(p<0.05)$

\begin{tabular}{|c|c|c|c|c|c|c|c|c|c|}
\hline \multirow{3}{*}{\multicolumn{2}{|c|}{$\begin{array}{c}\text { Analysed } \\
\text { period }\end{array}$}} & \multicolumn{4}{|c|}{ Nowa Huta station } & \multicolumn{4}{|c|}{ Kurdwanow station } \\
\hline & & \multicolumn{2}{|c|}{2014} & \multicolumn{2}{|c|}{2015} & \multicolumn{2}{|c|}{2014} & \multicolumn{2}{|c|}{2015} \\
\hline & & $r$ & $r^{2}$ & $r$ & $r^{2}$ & $r$ & $r^{2}$ & $r$ & $r^{2}$ \\
\hline \multirow{12}{*}{ 壳 } & 1 & 0.716 & 0.513 & 0.748 & 0.559 & 0.694 & 0.481 & 0.649 & 0,422 \\
\hline & 2 & 0.449 & 0.202 & 0.609 & 0.370 & 0.463 & 0.214 & 0.705 & 0,497 \\
\hline & 3 & 0.549 & 0.301 & 0.496 & 0.246 & 0.576 & 0.332 & 0.487 & 0,237 \\
\hline & 4 & 0.380 & 0.144 & 0.434 & 0.188 & 0.465 & 0.216 & 0.478 & 0,228 \\
\hline & 5 & 0.467 & 0.218 & 0.478 & 0.229 & 0.455 & 0.207 & 0.406 & 0,164 \\
\hline & 6 & 0.358 & 0.128 & 0.455 & 0.207 & 0.454 & 0.206 & 0.392 & 0,154 \\
\hline & 7 & 0.393 & 0.154 & \multirow{2}{*}{\multicolumn{2}{|c|}{$\begin{array}{c}\text { wind speed } \\
\text { measurements } \\
\text { unavailable }\end{array}$}} & 0.348 & 0.121 & 0.606 & 0.368 \\
\hline & 8 & 0.501 & 0.251 & & & 0.503 & 0.253 & 0.501 & 0.251 \\
\hline & 9 & 0.302 & 0.091 & 0.397 & 0.157 & 0.359 & 0.129 & 0.563 & 0,317 \\
\hline & 10 & 0.470 & 0.221 & 0.487 & 0.237 & 0.518 & 0.268 & 0.660 & 0,436 \\
\hline & 11 & 0.567 & 0.322 & 0.700 & 0.490 & 0.723 & 0.522 & 0.691 & 0,477 \\
\hline & 12 & 0.835 & 0.698 & 0.652 & 0.425 & 0.720 & 0.518 & 0.656 & 0,430 \\
\hline \multicolumn{2}{|c|}{$\begin{array}{l}\text { Heating } \\
\text { season }\end{array}$} & 0.632 & 0.399 & 0.603 & 0.363 & 0.611 & 0.374 & 0.620 & 0.384 \\
\hline \multicolumn{2}{|c|}{$\begin{array}{l}\text { Non-heating } \\
\text { season }\end{array}$} & 0.358 & 0.128 & 0.403 & 0.162 & 0.373 & 0.139 & 0.463 & 0.214 \\
\hline \multicolumn{2}{|c|}{ Year } & 0.340 & 0.115 & 0.421 & 0.177 & 0.374 & 0.140 & 0.394 & 0.156 \\
\hline
\end{tabular}

In addition, Figures 10 and 11 illustrate the dilution effect of pollutants resulting from the daily cyclic changes in the height of mixing layer during the period with very low wind speeds (14-16.12.2014).

Conducted analysis shows that low mixing-layer height (up to $100 \mathrm{~m}$ ) occurred in the area of the analysed monitoring stations for aprrox. 38-40\% of the time throughout the year, and was most frequent in cold months. Low mixinglayer height was often associated with low wind speed (or calm wind) episodes. Therefore, such adverse aerosanitary conditions may be one of the major causes for significant deterioration of air quality in Krakow during the heating season. 


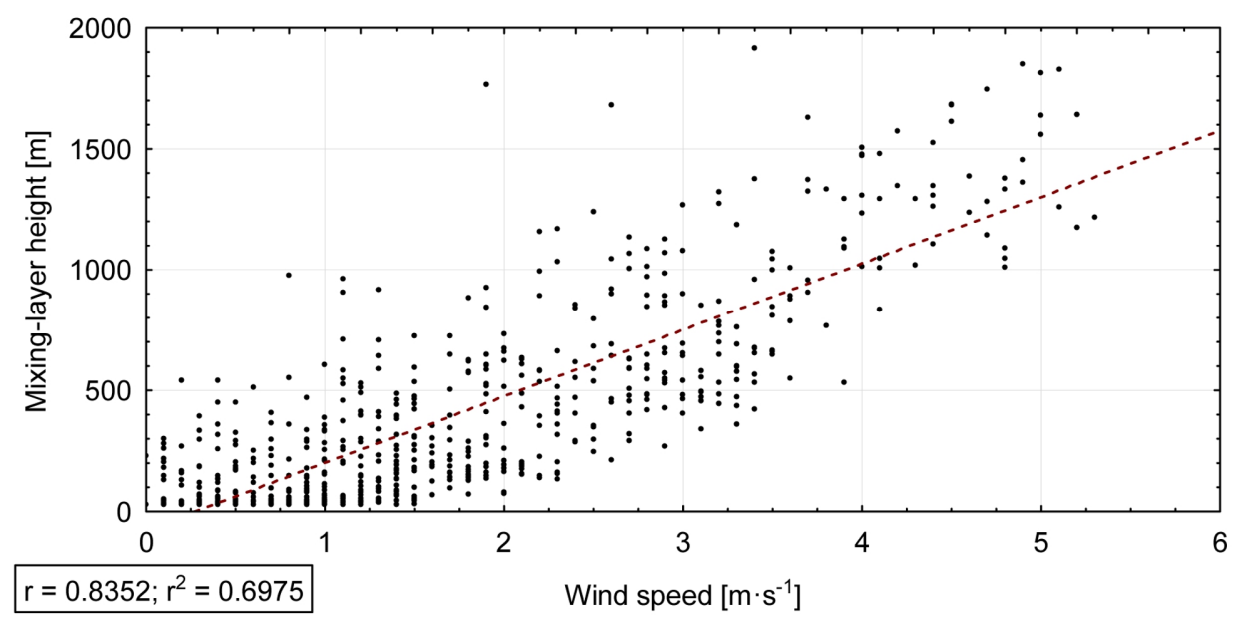

Fig. 8. Relationship between the mixing-layer height and wind speed obtained for the Nowa Huta station in December 2014 (1-hour averaged data)

\section{Conclusions}

Krakow, due to its unfavourable location in the valley and high level urban density, is a city characterized by poor ventilation properties, which combined with large amounts of local emission sources contribute to the occurrences of significant air pollution, especially in the heating season. In such situation the variability of meteorological parameters is of great importance, as it determines the potential dilution of pollutants in areas with high concentrations. On the basis of studies and analysis carried out for a period of two years (2014-2015) it can be concluded, that the concentrations of most air pollutants present in Krakow in the area of industrial station (Nowa Huta) and urban background station (Kurdwanow) are correlated with wind speed and mixing-layer height.

The strongest negative correlation between the concentrations of certain pollutants in the air and the wind speed/height of mixing layer occurs in winter months and concerns the following substances: $\mathrm{PM}_{10}, \mathrm{PM}_{2.5}$ and $\mathrm{NO}_{\mathrm{x}}$ (measured at both of the stations) and $\mathrm{CO}$ and $\mathrm{C}_{6} \mathrm{H}_{6}$ (measured only at the Nowa Huta station). This conclusion is evidenced by relatively high Spearman's rank correlation coefficients $\left(\left|r_{s}\right|>0.5\right)$ obtained for analysed data with a temporal resolution of 1 hour.

During the heating season the cumulative impact of both meteorological parameters mentioned above is observed, which intensifies the dilution and concentration processes of pollutants within the mixing zone. These factors are mutually partially correlated, which is especially evident in the winter months. In extreme cases, the Pearson correlation coefficient between wind speed and mixing-layer height reaches the level of 0.83 (Nowa Huta station, December 
2014), with the average value for both of the analysed stations throughout the heating season equal to 0.62 .

a)

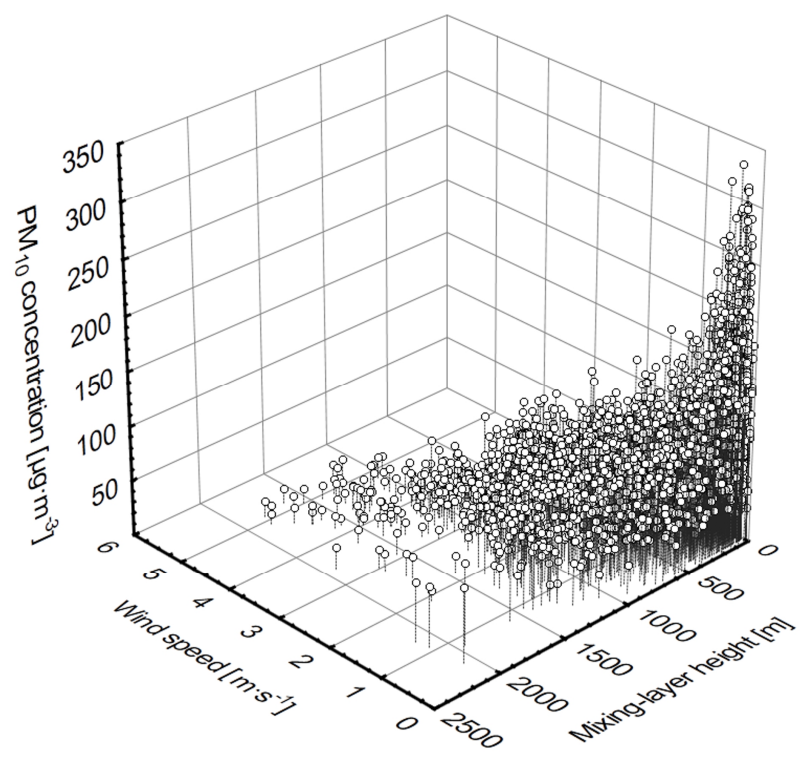

b)

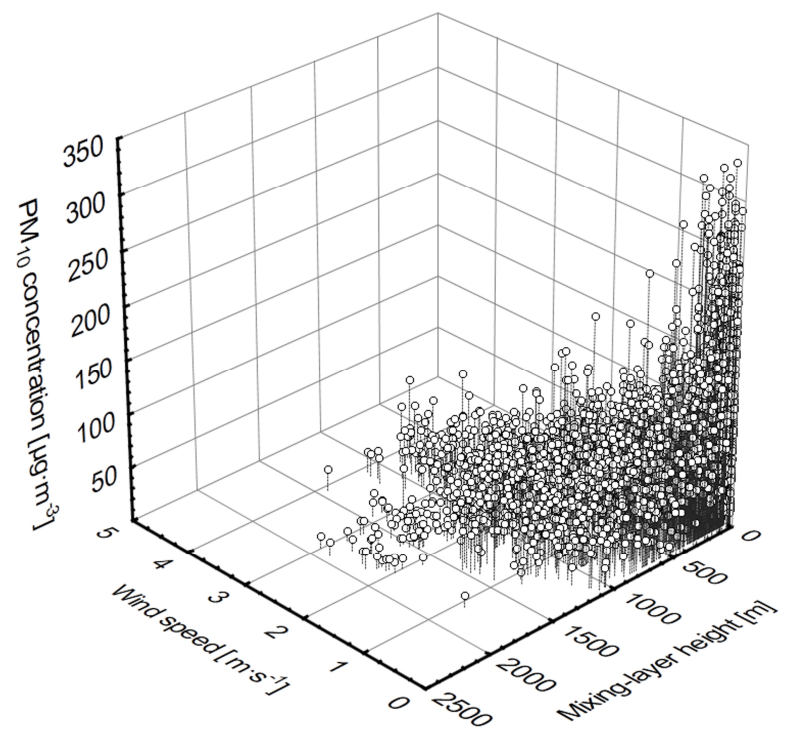

Fig. 9. The cumulative impact of wind speed and mixing-layer height on the $\mathrm{PM}_{10}$ levels in the air recorded during the heating season at the analysed stations: a) Nowa Huta, b) Kurdwanow (1-hour averaged data from 2014) 

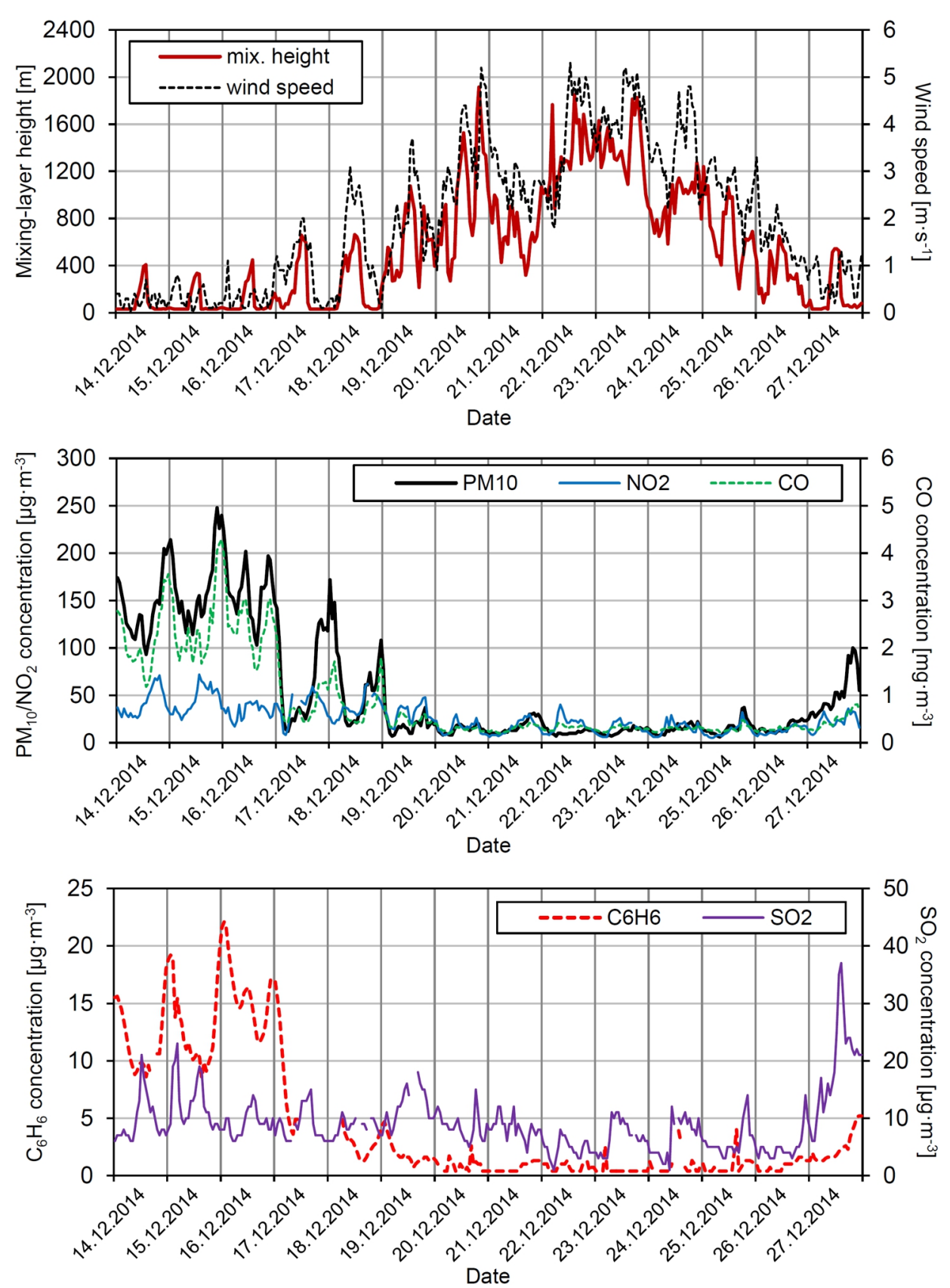

Fig. 10. Variability of the analysed meteorological parameters and concentrations of selected air pollutants at the Nowa Huta station in the period of 14-27.12.2014 (1-hour averaged values) 

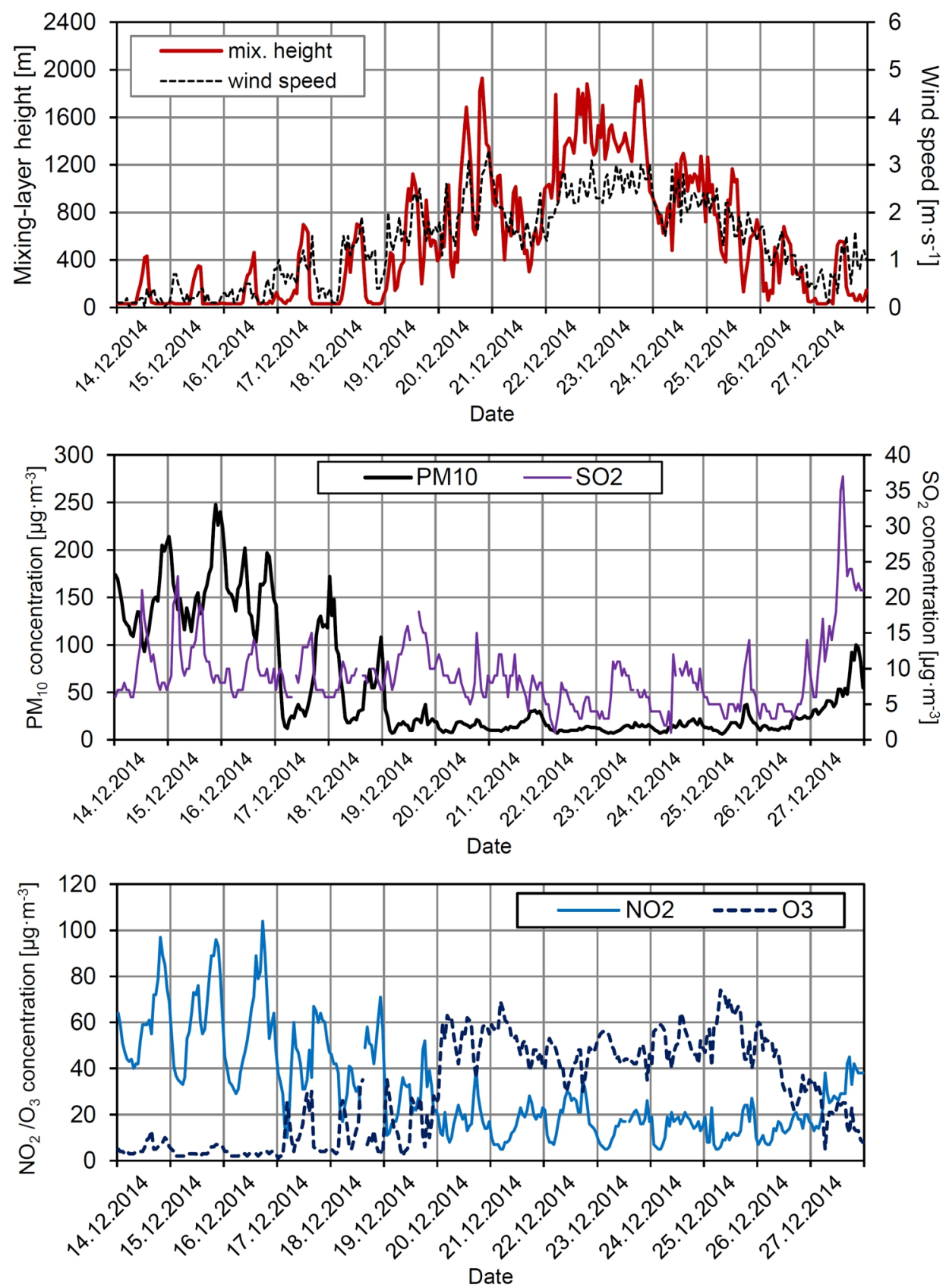

Fig. 11. Variability of the analysed meteorological parameters and concentrations of selected air pollutants at the Kurdwanow station in the period of 14-27.12.2014 (1- hour averaged values) 
In the case of $\mathrm{O}_{3}$ concentrations, measured only at the Kurdwanow station, for all of the months in the year a relatively high positive correlation was found in relation to both of the analysed meteorological parameters. This may be involved, among others, with the inflow of the air rich in $\mathrm{O}_{3}$ and other oxidising substances or hydrocarbons (which are the sources of radicals accelerating the conversion of $\mathrm{NO}$ to $\mathrm{NO}_{2}$ and ozone formation). On the other hand, it may result from blowing away the air rich in NO from the analysed area, which could react with $\mathrm{O}_{3}$ and reduce its concentration in the air. During warmer months the increase of the mixing-layer height is associated with strong convection that results from increased insolation level and higher temperature, which promotes the formation of ozone.

At this station, a significant reduction in the $\mathrm{NO}_{2}$ and $\mathrm{NO}_{\mathrm{x}}$ concentrations during the non-heating season with an increase of both wind speed and mixinglayer height was observed. This information can indicate that this station is subjected to a significant impact of the nearby road traffic and industrial emission and may point to dilution processes of pollutants (and air pollution plumes from point sources) resulting from an increase in wind speed and mixing-layer height. During the months characterized by intense solar radiation $\mathrm{NO}_{2}$ undergoes photodissociation, thus causing the formation of ozone, peroxyacetyl nitrate (PAN) and other organic peroxides which is also promoted by mixing effects.

The weakest relationship between the concentrations in the air and the wind speed or the mixing-layer height was obtained for $\mathrm{SO}_{2}$, and periodically for the Nowa Huta station in case of $\mathrm{NO}_{2}$ as well. Furthermore, these correlations defined for individual months are characterized by a noticeable variability and, example given, for $\mathrm{SO}_{2}$ concentrations measured at the Nowa Huta station in 2014-2015 they were generally of positive value. The increase in $\mathrm{SO}_{2}$ concentrations in the air with increasing wind speed and mixing-layer height appears to be caused by intensified inflow of this substance (air masses with its higher concentrations) from other regions, including more distant residential areas of singlefamily detached houses and industrial emission sources located along the dominant wind directions. On the other hand, periodically occurring lack of correlation of analysed meteorological parameters with $\mathrm{NO}_{2}$ concentrations may partly be due to the mutual neutralisation of two effects: dilution of this substance in the air and accelerated oxidation of $\mathrm{NO}$ to $\mathrm{NO}_{2}$ as a result of the inflow of oxidants from the areas where they are in abundance. In the case of the Nowa Huta station, direct impact of vapour emissions of volatile organic compounds and other pollutants from a nearby gas station, roads transport and industrial plants may also be crucial.

Impact assessment of wind speed and mixing-layer height on the pollutant concentrations conducted in the paper for two measurement points located in the city of Krakow provides partial explanation for the reasons behind the episodes with elevated concentrations of certain pollutants in the air, which are recorded at the analysed monitoring stations. Furthermore, performed analysis allowed for 
the examination of both causes and nature of periodically occurring noticeable improvement of air quality in the city. However, further analysis taking into account greater number of parameters and measurement points is advisable, together with the evaluation of mixing-layer height temporal variability determined in the paper using mathematical modelling.

\section{This paper has been prepared within the scope of the AGH UST statutory research no. 11.11.150.008.}

\section{Literature}

[1] Akpinar S., Oztop H.F., Akpinar E.K.: Evaluation of relationship between meteorological parameters and air pollutant concentrations during winter season in Elaziğ, Turkey, Environmental Monitoring and Assessment, vol. 146, 2008, pp. 211-224.

[2] Bogacki M.: Wpływ sposobu zagospodarowania terenu na potencjał oksydacyjny powietrza, Inżynieria Środowiska, t. 8, z. 2, 2003, s. 135-147.

[3] Chief Inspectorate for Environmental Protection (Poland): Air quality portal, http://powietrze.gios.gov.pl/ \{ accessed in 31.01.2016\}.

[4] Chuang M.T., Chiang P.C., Chan C.C., Wang C.F., Chang E.E., Lee C.T.: The effects of synoptical weather pattern and complex terrain on the formation of aerosol events in the Greater Taipei area. Science of the Total Environment, vol. 399, 2008, pp. 128-146.

[5] Czarnecka M., Nidzgorska-Lencewicz J.: Impact of weather conditions on winter and summer air quality, International Agrophysics, vol. 25, 2011, pp. 7-12.

[6] Czarnecka M., Nidzgorska-Lencewicz J.: Warunki meteorologiczne kształtujące jakość powietrza w styczniu i w lipcu 2006 roku w Szczecinie, Acta Agrophysica vol. 12(1), 2008, s. 55-72.

[7] Ćwiek K., Majewski G.: Wpływ elementów meteorologicznych na kształtowanie się stężeń zanieczyszczeń powietrza na przykładzie Krakowa, Przegląd Naukowy Inżynieria i Kształtowanie Środowiska, nr 67, 2015, s. 54-66.

[8] Drzeniecka A., Pereyma J., Pyka J.L., Szczurek A.: Wpływ warunków meteorologicznych na stężenie zanieczyszczeń powietrza w śródmieściu Wrocławia, Chemia i Inżynieria Ekologiczna, vol. 7, nr 8-9, 2000, s. 865-882.

[9] Godłowska J., Kaszowski W., Hajto M.J., Tomaszewska A.M.: Wpływ sposobu przygotowania meteorologicznych danych wejściowych w systemie FAPPS na jakość pola wiatru i głębokość mieszania, Konsekwencje dla prognozy PM10, [w:] Ochrona powietrza w teorii i praktyce. Tom 2 (red. J. Konieczyński), IPIŚ PAN, Zabrze 2012, s. 75-88.

[10] Gorai A.K., Tuluri F., Tchounwou P.B., Ambinakudige S.: Influence of local meteorology and $\mathrm{NO}_{2}$ conditions on ground-level ozone concentrations in the eastern part of Texas, USA, Air Quality, Atmosphere \& Health, vol. 8, 2014, pp. 81-96.

[11] Guttikunda S.K., Gurjar B.R.: Role of meteorology in seasonality of air pollution in megacity Delhi, India, Environmental Monitoring and Assessment, vol. 184, 2012, pp. 3199-3211. 
[12] Isyumov D., Helliwell N., Rosen S., Lai S.: Winds in Cities: Effects on Pedestrians and the Dispersion of Ground Level Pollutants, [w:] Wind Climate in Cities (ed. J.E. Cermak, A.G. Davenport, E.J. Plate, D.X. Viegas), Springer, 1995, pp. 319-335.

[13] Juda-Rezler, K., Reizer, M., Oudinet, J.P.: Determination and analysis of PM $_{10}$ source apportionment during episodes of air pollution in Central Eastern European urban areas: the case of wintertime 2006, Atmospheric Environment, vol. 45, 2011, pp. 6557-6566.

[14] Kim K.H., Lee S.-B., Woo D., Bae G.-N.: Influence of wind direction and speed on the transport of particle-bound PAHs in a roadway environment, Atmospheric Pollution Research, vol. 6, 2015, pp. 1024-1034.

[15] Kompalli S.K., Babu S.S., Moorthy K.K., Manoj, M. R., Kumar, N. K., Shaeb, K. H. B., \& Joshi, A. K.: Aerosol black carbon characteristics over Central India: Temporal variation and its dependence on mixed layer height, Atmospheric Research, vol. 147, 2014, pp. 27-37.

[16] Kwak K.-H., Lee S.-H., Seo J.M., Park S.-B., Baik J.-J.: Relationship between rooftop and on-road concentrations of traffic-related pollutants in a busy street canyon: Ambient wind effects, Environmental Pollution, vol. 208, 2016, pp. 185-197.

[17] Lai L.W.: Fine particulate matter events associated with synoptic weather patterns, long-range transport paths and mixing height in the Taipei Basin, Taiwan, Atmospheric Environment, vol. 113, 2015, pp. 50-62.

[18] Lin J. T., McElroy M. B.: Impacts of boundary layer mixing on pollutant vertical profiles in the lower troposphere: Implications to satellite remote sensing, Atmospheric Environment, vol. 44, 2010, pp. 1726-1739.

[19] Lo K.W., Ngan K.: Characterising the pollutant ventilation characteristics of street canyons using the tracer age and age spectrum, Atmospheric Environment, vol. 122, 2015, pp. 611-621.

[20] Majewski G.: Zanieczyszczenie powietrza pyłem zawieszonym PM10 na Ursynowie i jego związek z warunkami meteorologicznymi, Przegląd Naukowy - Inżynieria i Kształtowanie Środowiska, 1(31), 2005, s. 210-223.

[21] National Climatic Data Center (NCDC): Integrated Surface Data (ISD), ftp://ftp.ncdc.noaa.gov/pub/data/noaa/2012/ \{accessed in 31.12.2015\}.

[22] Nkemdirim L.C.: The Role of Wind Velocity and Mixing Depth in the Distribution of Urban Air Pollution Hazard in Calgary, Alberta, Canada, GeoJournal, vol. 8(3), 1984, pp. 197-200.

[23] NOAA Earth System Research Laboratory (ESRL): Radiosonda Database, http://esrl.noaa.gov/raobs/ \{accessed in 31.12.2015\}.

[24] Ocak S., Turalioglu F.: Effect of Meteorology on the Atmospheric Concentrations of Traffic-Related Pollutants in Erzurum, Turkey, J. Int. Environmental Application \& Science, vol. 3(5), 2008, pp. 325-335.

[25] Oleniacz R., Bogacki M., Rzeszutek M., Kot A.: Meteorologiczne determinanty jakości powietrza w Krakowie, [w:] Ochrona powietrza w teorii i praktyce. Tom 2 (red. J. Konieczyński), Wyd. IPIŚ PAN w Zabrzu, Zabrze, 2014, s. 163-178. 
[26] Oleniacz R., Rzeszutek M.: Determination of optimal spatial databases for the area of Poland to the calculation of air pollutant dispersion using the CALMET/CALPUFF model, Geomatics and Environmental Engineering, vol. 8, no. 2, 2014, pp. 57-69.

[27] Oleniacz R., Rzeszutek M.: Assessment of the impact of spatial data on the results of air pollution dispersion modeling, Geoinformatica Polonica, vol. 13, 2014, pp. 57-68.

[28] Olofson K.F.G., Andersson P.U., Hallquist M., Ljungström E., Tang L., Chen D., Pettersso, J.B.: Urban aerosol evolution and particle formation during wintertime temperature inversions, Atmospheric Environment, vol. 43, 2009, pp. 340-346.

[29] Panda S., Sharma S.K., Mahapatra P.S., Panda U., Rath S., Mahapatra M., Mandal T.K., Das T.: Organic and elemental carbon variation in PM2.5 over megacity Delhi and Bhubaneswar, a semi-urban coastal site in India, Natural Hazards, vol. 80, 2016, pp. 1709-1728.

[30] Perez-Martinez P.J., Miranda R.M.: Temporal distribution of air quality related to meteorology and road traffic in Madrid, Environmental Monitoring and Assessment, vol. 187, 2015, pp. 1-16.

[31] Pietras B.: Czynniki meteorologiczne wpływające na koncentrację aerozoli w Krakowie oraz analiza cząstek aerozoli, Prace Studenckiego Koła Naukowego Geografów Uniwersytetu Pedagogicznego w Krakowie, vol. 2, 2014, s. 90-100.

[32] Raman R.S., Kumar S.: First measurements of ambient aerosol over an ecologically sensitive zone in Central India: Relationships between PM2.5 mass, its optical properties, and meteorology, Science of The Total Environment, vol. 550, 2016, pp. 706-716.

[33] Rawicki K.: Variability of particulate matter concentrations in Poland in the winter 2012/2013, Folia Pomeranae Universitatis Technologiae Stetinensis. Agricultura, Alimentaria, Piscaria et Zootechnica, vol. 31, 2014, pp. 143-151.

[34] Rozporządzenie Ministra Środowiska z dnia 13 września 2012 r. w sprawie dokonywania oceny poziomów substancji w powietrzu, Dz. U. 2012, poz. 1032.

[35] Schäfer K., Wagner P., Emeis S., Jahn C., Muenkel C., Suppan P.: Mixing layer height and air pollution levels in urban area, [in:] Proc. of. SPIE, Remote Sensing of Clouds and the Atmosphere XVII; and Lidar Technologies, Techniques, and Measurements for Atmospheric Remote Sensing VIII (ed. E.I. Kassianov et al.), vol. 8534, 853409, 2012, pp. 1-10.

[36] Scire J.S., Robe F.R., Fernau M.E., Yamartino R J.: A User's Guide for the CALMET Meteorogical Model (Version 5), Concord 2000.

[37] Seinfeld J.H., Pandis S.N., Atmospheric chemistry and physics: from air pollution to climate change, 3rd Edition, John Wiley \& Sons, 2016.

[38] Tiwari S., Bisht D.S., Srivastava A.K., Pipal A.S., Taneja A., Srivastava M.K., Attri S.D.: Variability in atmospheric particulates and meteorological effects on their mass concentrations over Delhi, India, Atmospheric Research, vol. 145, 2014, pp. 45-56.

[39] Wagner P., Schäfer K.: Influence of mixing layer height on air pollutant concentrations in an urban street canyon, Urban Climate, 2015, doi: 10.1016/j.uclim.2015.11.001. 
[40] Walczewski, J.: Niektóre dane o występowaniu całodziennych warstw inwersyjnych w atmosferze Krakowa i uwarunkowania tego zjawiska, Przegląd Geofizyczny, z. 3-4, 2009, s. 183-191.

[41] Weber S., Kordowski K., Kuttler W.: Variability of particle number concentration and particle size dynamics in an urban street canyon under different meteorological conditions, Science of the Total Environment, vol. 449, 2013, pp. 102-114.

[42] Wojewódzki Inspektorat Ochrony Środowiska w Krakowie: System monitoring jakości powietrza, http://monitoring.krakow.pios.gov.pl/ \{accessed in 31.01.2016\}.

[43] Wydział Fizyki i Informatyki Stosowanej AGH w Krakowie: Serwis METEO, http://meteo.ftj.agh.edu.pl/meteo/ \{accessed in 31.01.2016\}.

[44] Xu J., Yan F., Xie Y., Wang F., Wu J., Fu Q.: Impact of meteorological conditions on a nine-day particulate matter pollution event observed in December 2013, Shanghai, China, Particuology, vol. 20, 2015, pp. 69-79.

[45] Żyromski A., Biniak-Pieróg M., Burszta-Adamiak E., Zamiar Z.: Evaluation of relationship between air pollutant concentration and meteorological elements in winter months, Journal of Water and Land Development, vol. 22, 2014, pp. 25-32.

\title{
OCENA WPEYWU PRĘDKOŚCI WIATRU I WYSOKOŚCI WARSTWY MIESZANIA NA JAKOŚĆ POWIETRZA W KRAKOWIE (POLSKA) W LATACH 2014-2015
}

\begin{abstract}
Streszczenie
W pracy omówiono rolę, jaką pełni prędkość wiatru i wysokość warstwy mieszania w kształtowaniu poziomów stężeń zanieczyszczeń w powietrzu w Krakowie (Południowa Polska). W tym celu wykorzystano 1-godzinne wyniki pomiarów stężeń wybranych zanieczyszczeń powietrza oraz prędkości wiatru z okresu 2014-2015, realizowanych w obszarze miasta Krakowa w dwóch stacjach monitoringu jakości powietrza (stacji przemysłowej i tła miejskiego). Czasową zmienność wysokości warstwy mieszania w rejonie danej stacji monitoringowej wyznaczono metodą modelowania z wykorzystaniem modelu CALMET i wyników pomiarów pochodzących m.in. z dwóch stacji aerologicznych. Stwierdzono co najmniej umiarkowaną zależność pomiędzy prędkością wiatru i wysokościa warstwy mieszania oraz stężeniami niektórych zanieczyszczeń powietrza. W przypadku takich substancji, jak $\mathrm{PM}_{10}, \mathrm{PM}_{2,5}, \mathrm{NO}_{2}, \mathrm{NO}_{\mathrm{x}}, \mathrm{CO}$ i $\mathrm{C}_{6} \mathrm{H}_{6}$ korelacja ta jest ujemna, co świadczy o tym, że niska prędkość wiatru i mała wysokość warstwy mieszania może być główną przyczyną podwyższonych stężeń tych substancji w powietrzu, zwłaszcza w miesiącach zimowych. Dla $\mathrm{O}_{3}$ otrzymano korelację dodatnią z analizowanymi parametrami meteorologicznymi, świadczącą o tym, że w tworzeniu się ozonu istotną rolę odgrywa dostępność do odpowiednich prekursorów i intensywność ich napływu z sąsiednich terenów. Z kolei w przypadku $\mathrm{SO}_{2}$ uzyskano słabe korelacje dodatnie lub ujemne w zależności od rozpatrywanego okresu roku i lokalizacji stacji.
\end{abstract}

Słowa kluczowe: zanieczyszczenie powietrza, stężenia zanieczyszczeń, parametry meteorologiczne, analiza korelacji, przewietrzanie miasta, CALMET 
DOI: $10.7862 / \mathrm{rb} .2016 .168$

Przestano do redakcji: 01.05.2016 $r$.

Przyjęto do druku: 28.06.2016 r. 